\title{
Balanceren tussen een taakverdeling en collegialiteit binnen de raad
}

\author{
De verhouding tussen auditcommissieleden en overige commissarissen bezien in het \\ licht van geagendeerde wet- en regelgeving
}

\author{
Mr.drs.L.in 't Veld*
}

\begin{abstract}
De auditcommissie heeft een vaste positie verworven binnen het Nederlandse vennootschapsrecht. Recente ontwikkelingen accentueren de onduidelijkheid die bestaat over de verhouding tussen auditcommissieleden en overige leden van de raad. De auteur meent dat het evenwicht dient te worden bewaakt tussen een ver(der)gaande taakverdeling en het beginsel van collegialiteit binnen de raad.
\end{abstract}

\section{Inleiding}

De geschiedenis lijkt zich te hebben herhaald wat de positie van de balanscommissaris betreft. De balanscommissaris, eind jaren twintig van de vorige eeuw geïntroduceerd als de specifiek met het toezicht op de financiële verslaggeving belaste commissaris, ${ }^{1}$ verdween met de inwerkingtreding van de Wet op de jaarrekening van ondernemingen ${ }^{2}$ weer uit het Nederlandse vennootschapsrecht. In de memorie van toelichting bij het voorstel voor die wet werd daarover het volgende opgemerkt:

'Een verdere wijziging geldt het voorstel in het tweede lid de vermelding van de zogenaamde balanscommissarissen als afzonderlijke groep te laten vervallen. Het komt de ondergetekende evenals de Commissie Ondernemingsrecht voor dat het toezicht op, en het dragen van verantwoordelijkheid voor de jaarrekening een zo essentieel onderdeel van de taak van de commissarissen is, dat geen der commissarissen hiervan kan worden ontheven. ${ }^{3}$

Inmiddels, ruim veertig jaar nadat het Nederlandse vennootschapsrecht afscheid nam van het onderscheid tussen de balanscommissaris en de overige leden van de raad van commissarissen (hierna: de raad), valt een vergelijkbaar onder-

\footnotetext{
Mr. drs. L. in 't Veld is als wetenschappelijk docent en onderzoeker verbonden aan Erasmus School of Law en verbonden aan het Instituut voor Ondernemingsrecht ( $\mathrm{IvO})$ en het IvO Center for Financial Law \& Governance (ICFG). Het winnen van de DVDW Scriptieprijs 2015 vormt de aanleiding voor deze bijdrage. De auteur dankt Paul van Ooik voor zijn bijdrage aan het empirisch onderzoek.

1. Wet van 2 juli 1928, Stb. 1928, 216.

2. Stb. 1970,414 .

3. Kamerstukken II 1967/68, 9595, 3, p. 22.
}

scheid te maken tussen de leden van de raad die lid zijn van een auditcommissie en zij die dat niet zijn. ${ }^{4}$ De introductie van de auditcommissie, een goed Anglo-Amerikaans gebruik bij vennootschappen met een monistisch bestuursmodel (onetier board), heeft in de literatuur geleid tot betrekkelijk veel onduidelijkheid over de verhouding tussen de leden van de auditcommissie en de overige leden van de raad, al dan niet in verband met een mogelijk verhoogd aansprakelijkheidsrisico waaraan eerstgenoemden worden blootgesteld. ${ }^{5}$

De discussie omtrent het door de leden van de auditcommissie uitgeoefende toezicht is hoogst actueel. ${ }^{6}$ Richtlijn 2014/56/ EU (hierna: Wijziging Audit Richtlijn) diende uiterlijk 17 juni 2016 in Nederlandse wetgeving te zijn geïmplementeerd.? Vanaf diezelfde datum is Verordening (EU) 537/2014 (hierna: Audit Verordening) van toepassing. Een wetsvoorstel ter implementatie van de Wijziging Audit Richtlijn en ter uitvoering van de Audit Verordening is uiteindelijk op 13 mei 2016 aan de Tweede Kamer toegezonden. ${ }^{8}$ De - vertraagde implementatie van de Wijziging Audit Richtlijn en de Audit Verordening zullen scherpere deskundigheids- en onafhankelijkheidseisen stellen aan de leden van de auditcommissie en zullen de taken - en verantwoordelijkheden - van de leden

4. Zie P.M. van der Zanden, Accountants in de problemen! Balanscommissaris, een panacee?, Ondernemingsrecht 2014/96, p. 498. Vgl. H. Beckman, Enkele losse gedachten bij en over commissaris, toezicht en controle, Ondernemingsrecht 2005/86, p. 251-252; J. Biesheuvel-Hoitinga, De civielrechtelijke balansaansprakelijkheid van commissarissen bij beursvennootschappen, Ondernemingsrecht 2010/142, p. 678.

5. Zie M.J. Kroeze, Bange bestuurders, Ondernemingsrecht 2006/3, p. 7 , waarin Kroeze een commissaris aanhaalde die het lidmaatschap van de auditcommissie vanwege het aansprakelijkheidsrisico dat daarop rust - enigszins gechargeerd - omschreef als 'zo langzamerhand de grootste klotebaan van Nederland'. Zie voorts J.B. Wezeman, De toezichthoudende rol van commissarissen en 'auditcommissies', TvJ 2009, afl. 4, p. 89; Van der Zanden 2014, p. 494.

6. Daarover tevens: H.H. Kersten, De rol van de auditcommissie bij het toezicht door de raad van commissarissen op risicobeheer, Ondernemingsrecht 2016/14.

7. De Wijziging Audit Richtlijn strekt tot wijziging van Richtlijn 2006/43/ EG (Audit Richtlijn).

8. Kamerstukken II 2015/16, 34469, 2. Daarover: J.B.S. Hijink, Het gezag van de wet(gever) en toezichthouder, Ondernemingsrecht 2016/60. 
van de auditcommissie verder doen uitbreiden. ${ }^{9}$ Tevens zal de Autoriteit Financiële Markten (AFM) het functioneren van auditcommissies monitoren. Daarop heeft zij door middel van een (verkennend) onderzoek reeds geanticipeerd. ${ }^{10}$ Tot slot heeft de Monitoring Commissie Corporate Governance Code onder voorzitterschap van Van Manen (hierna: commissieVan Manen) voorstellen gepubliceerd voor herziening van de Nederlandse Corporate Governance Code, waarin zij onder andere voorstelt de rol van de auditcommissie te verduidelijken en, op specifieke onderdelen, verder te verbreden.

Deze bijdrage richt zich primair op de positie van de auditcommissie van de beurs-NV binnen het Nederlandse vennootschapsrecht en de gevolgen die het lidmaatschap van de auditcommissie heeft voor het aansprakelijkheidsrisico waaraan leden van de auditcommissie mogelijk worden blootgesteld. ${ }^{11}$ Daarbij beperkt deze bijdrage zich hoofdzakelijk tot de positie van de auditcommissie van de beurs-NV met een dualistisch bestuursmodel (two-tier board). ${ }^{12}$

De indeling van deze bijdrage is als volgt. In paragraaf 2 behandel ik de positie van de auditcommissie binnen het Nederlandse vennootschapsrecht. Vervolgens sta ik in paragraaf 3 stil bij de mogelijkheid van een taakverdeling binnen het bestuur en de raad en de mogelijke gevolgen daarvan voor de aansprakelijkheidsposities van de leden van deze vennootschapsorganen. In paragraaf 4 zal ik nader ingaan op de ver-

9. Zie voor de aanvullende taken en de aangescherpte samenstellingseisen art. 1 lid 32 Wijziging Audit Richtlijn, dat strekt tot wijziging van art. 41 Audit Richtlijn. Daarover: consultatieversie MvT bij het Implementatiebesluit wijzigingsrichtlijn en verordening wettelijke controles jaarrekeningen, p. 31 e.v., te raadplegen via <www.internetconsultatie.nl/ implementatiebesluitaccountancy>.

10. Zie AFM, Rapport Auditcommissies. Verkenning naar kritisch vermogen auditcommissies bij verslaggeving en accountantscontrole, maart 2015. Daarover in kritische zin: V.P.G. de Serière, Een rivier treedt buiten haar oevers... Waar is de dijkgraaf?, Ondernemingsrecht 2015/35, p. 196.

11. Onder de beurs-NV wordt in deze bijdrage verstaan de statutair in Nederland gevestigde vennootschap wier (certificaten van) aandelen (primair) zijn toegelaten tot de handel op een gereglementeerde markt in Nederland. Aldus laat ik in deze bijdrage buiten beschouwing (1) de statutair in Nederland gevestigde vennootschap wier (certificaten van) aandelen (primair) zijn toegelaten tot de handel op een multilaterale handelsfaciliteit of een daarmee vergelijkbaar systeem in Nederland en (2) de statutair in Nederland gevestigde vennootschap wier (certificaten van) aandelen (primair) zijn toegelaten tot de handel op een gereglementeerde markt of een daarmee vergelijkbaar systeem of tot de handel op een multilaterale handelsfaciliteit of een daarmee vergelijkbaar systeem, gelegen buiten Nederland ('beurs-NV in den vreemde'; daarover: A.A. Bootsma $\&$ J.B.S. Hijink, De beurs-NV in den vreemde. Een perspectief op modernisering van het NV-recht, Ondernemingsrecht 2014/15; A.A. Bootsma, J.B.S. Hijink \& L. in 't Veld, Multiple corporate citizenship. Over de meervoudige 'nationaliteit' van beursvennootschappen en wat dat betekent voor wet- en regelgevers, Ondernemingsrecht 2015/120).

12. Daarmee zij niet gezegd dat een behandeling van de positie van de auditcommissie van de beurs-NV met een monistisch bestuursmodel minder relevant zou zijn. Integendeel, de commissie-Van Manen stelt dat zij een verschuiving van het dualistisch bestuursmodel naar het monistisch bestuursmodel constateert. Die constatering verdient echter een nuancering: per ultimo 2015 maken slechts tien van de in deze bijdrage centraal gestelde beurs-NV's gebruik van het monistisch bestuursmodel. Dat komt neer op circa $11 \%$ van de totale populatie. In gelijke zin: A.J.P. Schild \& L. Timmerman, Het nieuwe art. 2:9 BW, uitgelegd voor gewone bestuurders, WPNR 2014/7011. houding tussen de leden van de raad die lid zijn van een auditcommissie en zij die dat niet zijn. Daarbij betrek ik tevens geagendeerde wet- en regelgeving. In paragraaf 5 besluit ik met de conclusie dat van belang is dat de (Europese) wetgever het evenwicht dient te (blijven) bewaken tussen efficiënt(er) bestuur en toezicht door middel van een (nadere) functionele takkverdeling en het uitgangspunt van collegialiteit binnen de raad.

\section{De (vennootschapsrechtelijke) positie van de auditcommissie}

De positie van de auditcommissie binnen het Nederlandse vennootschapsrecht is een bijzondere. Als kerncommissie van de raad is de auditcommissie recentelijk het Nederlandse vennootschapsrecht binnengeslopen. ${ }^{13}$ Dat heeft ertoe geleid dat inmiddels, per ultimo $2015,67 \%$ van het aantal in deze bijdrage centraal gestelde beurs-NV's een auditcommissie heeft ingesteld. ${ }^{14}$ Alleen beurs-NV's van relatief kleine omvang lijken nog af te zien van het instellen van een afzonderlijke auditcommissie. ${ }^{15}$ Aan de opmars van de auditcommissie binnen het Nederlandse vennootschapsrecht liggen diverse oorzaken ten grondslag. Een daarvan was de ontwikkeling dat vennootschappen waarvan (certificaten van) aandelen waren toegelaten tot de handel van een effectenbeurs in de Verenigde Staten, massaal overgingen tot het instellen van een auditcommissie. $\mathrm{Zij}$ werden hiertoe verplicht op grond van de beursvoorschriften (listing rules) die op deze vennootschappen van toepassing zijn. ${ }^{16}$ Een andere oorzaak is dat een van de veertig aanbevelingen - aanbeveling 15 - van de Commissie Corporate Governance onder voorzitterschap van Peters (hierna: commissie-Peters) inhield dat de raad zou moeten overwegen uit zijn midden een aantal kerncommissies, waaronder de auditcommissie, in te stellen. ${ }^{17}$ Tot slot bestond ook op Europees niveau de behoefte om voor te schrijven dat elke beurs-NV over dient te gaan tot het instellen van een auditcommissie. Met name de twee laatstgenoemde ontwikkelingen zijn van invloed geweest op de positie die de auditcommissie bekleedt binnen het Nederlandse vennootschapsrecht.

Aanvankelijk zou volgens de commissie-Peters de rol van de auditcommissie beperkt moeten zijn tot het voorbereiden van

13. Zie H. Langman, De audit-commissie, Ondernemingsrecht 2005/89, p. 259 , waarin hij stelt dat de auditcommissie 'tot voor kort (...) een nagenoeg onbekend verschijnsel in het Nederlandse vennootschapsland [was]'.

14. Dat percentage ligt aanzienlijk hoger voor de beurs-NV's met notering aan de AEX (95\%) en de AMX (95\%) dan voor de beurs-NV's met notering aan de AScX (61\%) en de lokale fondsen (33\%).

15. De gemiddelde (mediane) marktkapitalisatie van de beurs-NV met auditcommissie bedraagt circa EUR 7,8 miljard (EUR 1,5 miljard). Voor de beurs-NV zonder auditcommissie ligt het gemiddelde (de mediaan) aanzienlijk lager: circa EUR 900 miljoen (EUR 41 miljoen). Zie voorts G.F. Maassen, F.A.J. van den Bosch \& H.W. Volberda, Het gebruik van toezichthoudende commissies binnen raden van commissarissen in beursgenoteerde ondernemingen, MAB december 2005, p. 651.

16. Zie Langman 2005 , p. 260.

17. Aanbeveling 15 van de commissie-Peters, Corporate governance in Nederland. De veertig aanbevelingen, 1997 (hierna: Rapport commissiePeters). 


\section{Maandblad \\ Ondernemingsrecht}

de besluitvorming van (een aantal taken van) de raad. ${ }^{18}$ Niettemin bedeelde de commissie-Peters de auditcommissie een aantal zeer specifieke taken toe. Daaronder behoorden onder meer (1) het toezicht op de kwaliteit van alle externe financiële rapportages, (2) het toezicht op de naleving van interne procedures en wet- en regelgeving en de beheersing van bedrijfsrisico's, en (3) het faciliteren van de communicatie met alsmede het beoordelen van de activiteiten en het functioneren van de accountant. ${ }^{19}$ De opvolger van de commissie-Peters, de Commissie Corporate Governance onder voorzitterschap van Tabaksblat (hierna: commissie-Tabaksblat), heeft vervolgens in 2003 in de Nederlandse Corporate Governance Code (hierna: Code Tabaksblat) opgenomen dat de vennootschap een auditcommissie slechts dient in te stellen indien de raad uit meer dan vier leden bestaat. ${ }^{20}$ Ten minste een van de leden van de auditcommissie dient als financieel expert relevante kennis en ervaring te hebben op de gebieden waarop de auditcommissie toezicht houdt. ${ }^{21}$ Uit principe III.5 van de Code Tabaksblat volgt dat de algemene taakstelling van de commissies verder ongewijzigd bleef ten opzichte van de aanbeveling van de commissie-Peters. De taak van de auditcommissie is ook in de Code Tabaksblat beperkt tot het voorbereiden van de besluitvorming van de raad. De verduidelijking dat de raad de verantwoordelijkheid blijft dragen voor de besluitvorming die is voorbereid door de commissies, is niet overgenomen uit de conceptversie die aan de Code Tabaksblat voorafging. ${ }^{22}$ Uit de verantwoording van de commissie-Tabaksblat blijkt niet wat de aanleiding voor haar is geweest om deze nuance uit de uiteindelijke Code Tabaksblat te schrappen. Wellicht heeft het reeds in de wet opgenomen beginsel van collectieve verantwoordelijkheid een rol gespeeld. ${ }^{23}$ De specifiek aan de auditcommissie toebedeelde taken werden in de Code Tabaksblat verduidelijkt, en tevens aanzienlijk uitgebreid ten opzichte van de taken die door de commissie-Peters werden aanbevolen. ${ }^{24}$ Het takenpakket van de auditcommissie werd dan ook als 'zwaar' beschouwd. ${ }^{25}$ Ook lijkt de toedeling van specifieke taken aan de auditcommissie de grenzen tussen bestuur en toezicht en tussen toezicht en controle te hebben vervaagd. ${ }^{26}$ De reikwijdte van de taakverdeling werd ten slotte in 2008 - inhoudelijk ongewijzigd - overgenomen in de door de Monitoring Commissie Corporate Governance Code onder

18. Rapport commissie-Peters, 3.2 .

19. Rapport commissie-Peters, 6.4 .

20. Principe III.5 van de Code Tabaksblat. In principe II.4 van de ter commentaar voorgelegde conceptversie van de Code Tabaksblat (hierna: Conceptcode Tabaksblat) was opgenomen dat de raad, ongeacht het aantal leden dat daarin zitting heeft, een auditcommissie instelt. De commissie heeft, als reactie op het commentaar van met name 'kleine' beurs-NV's dat het instellen van de commissies zal leiden tot een onnodige kostenverhoging en/of om andere redenen niet haalbaar is, de reikwijdte van de best practice bepaling verkleind.

21. Best practice bepaling III.5.7 van de Code Tabaksblat.

22. Principe II.4 van de Conceptcode Tabaksblat.

23. Daarover par. 3.

24. Zie o.a. best practice bepaling III.5.4 en principe V.2 van de Code Tabaksblat.

25. Zie overweging 47 van de verantwoording van het werk van de commissie bij de Code Tabaksblat. Daarover tevens: Langman 2005, p. 261.

26. Daarover: Langman 2005, p. 262; Kersten 2016, p. 64. voorzitterschap van Frijns (hierna: commissie-Frijns) geactualiseerde Corporate Governance Code (hierna: Code Frijns).

Enkele van de in de Code Tabaksblat en de Code Frijns voorgeschreven taken van de auditcommissie zijn met de implementatie van artikel 41 van de Audit Richtlijn in Nederlandse wetgeving omgezet. De implementatie van dat artikel vond plaats door middel van het besluit van 26 juli 2008 (hierna: Besluit auditcommissie). Artikel 2 van dat besluit schrijft voor dat een organisatie van openbaar belang (OOB) als bedoeld in artikel 1 onderdeel $l$ van de Wet toezicht accountantsorganisaties, waaronder de beurs- $\mathrm{NV}$, in beginsel een auditcommissie instelt die is samengesteld uit leden van de raad of, indien de OOB gebruik maakt van het monistisch bestuursmodel, uit leden van het bestuursorgaan die niet belast zijn met het uitvoerend bestuur. Lid 2 van dat artikel schrijft voor dat de auditcommissie van de OOB op enkele onderdelen dient te voldoen aan de Code Tabaksblat. ${ }^{27}$ De OOB kan ook een orgaan aanwijzen dat de taken van de auditcommissie uitoefent op grond van artikel 3 lid 3 van het Besluit auditcommissie. Dat zal dan doorgaans de raad zijn. ${ }^{28}$

De positie van de auditcommissie binnen het Nederlandse vennootschapsrecht wordt nader geaccentueerd door enkele recente ontwikkelingen op het gebied van wet- en regelgeving. Begin dit jaar publiceerde de commissie-Van Manen haar voorstellen voor herziening van de Code Frijns. ${ }^{29}$ In enkele van de door haar voorgestelde principes en best practice bepalingen laat de commissie-Van Manen blijken voorstander te zijn van een verduidelijkte en, op specifieke onderdelen, verder verbrede rol van de raad en de auditcommissie in het bijzonder. ${ }^{30} Z_{\mathrm{o}}$ is in de door de commissie-Van Manen voorgestelde best practice bepaling 1.5.1 bepaald dat de taken van de auditcommissie onder meer zien op het toezicht op de financiële verslaggeving en de risicobeheersing door het bestuur. De auditcommissie richt zich daarbij, in aanvulling op wat in geagendeerde wet- en regelgeving is vastgelegd, in ieder geval op (1) de relatie met en de naleving van aanbevelingen en de opvolging van opmerkingen van de interne auditor en de externe accountant, (2) de financiering, (3) de toepassing van informatie- en communicatietechnologie, en (4) het belasting-

27. Het betreft - meer specifiek - de onderdelen a, b, c en $f$ van best practice bepalingen III.5.4 en III.5.7 alsmede de principes V.2 en V.4 van de Code Tabaksblat.

28. Ruim de helft (65\%) van het aantal beurs-NV's dat geen auditcommissie heeft ingesteld, heeft de taken van de auditcommissie bij de gehele raad neergelegd. Een van de overige beurs-NV's heeft ervoor gekozen de verantwoordelijkheid voor het aandachtsgebied neer te leggen bij een van de commissarissen. Daar een individuele commissaris niet kwalificeert als vennootschapsorgaan, lijkt dat in strijd met art. 2 lid 3 van het Besluit auditcommissie. Bij de overige beurs-NV's zonder auditcommissie blijkt niet uit het jaarverslag bij welk vennootschapsorgaan de taken van de auditcommissie zijn neergelegd. Ook dat lijkt in strijd met voormeld artikellid.

29. Zie - meer in het algemeen - over de voorstellen van de commissie-Van Manen F.G.K. Overkleeft \& J.H.L. Beckers, Het consultatievoorstel voor een herziene Code en langetermijnwaardecreatie: alleen 'jam tomorrow' of ook 'jam today', MvO 2016, afl. 3\&4, p. 43-46.

30. Zie p. 17 van de voorstellen van de commissie-Van Manen. 
beleid van de vennootschap. Tevens wordt de auditcommissie betrokken bij het toezicht op de cultuur en het gedrag binnen de met de vennootschap verbonden onderneming. ${ }^{31}$ Daarnaast zullen de implementatie van de Wijziging Audit Richtlijn en de Audit Verordening aanvullende taken aan de auditcommissie toebedelen en de deskundigheids- en onafhankelijkheidseisen van haar leden nader aanscherpen. ${ }^{32}$ De rol van de auditcommissie blijft in de Audit Richtlijn en de Audit Verordening, in tegenstelling tot de voorstellen van de commissie-Van Manen, echter wel beperkt tot het toezicht op het financiële verslaggevingsproces. ${ }^{33}$

De auditcommissie lijkt inmiddels een vaste positie binnen het Nederlandse vennootschapsrecht te hebben verworven als kerncommissie van de raad. Een apart vennootschapsorgaan, los van de raad, is zij echter (nog) niet. ${ }^{34}$ De vraag is hoe dit zich verhoudt tot de toedeling van specifieke toezichtstaken aan de leden van de auditcommissie. De relevantie van die vraag wordt versterkt door recente ontwikkelingen in wet- en regelgeving, die naar verwachting ertoe zullen leiden dat de taken - en daaruit voortvloeiende verantwoordelijkheden van de leden van de auditcommissie (nog) verder worden uitgebreid, wat de verhouding tussen hen en de overige leden van de raad (nog) verder lijkt te doen vertroebelen. ${ }^{35}$

\section{Van (collectieve) verantwoordelijkheid tot (individuele) aansprakelijkheid binnen de raad}

Met de inwerkingtreding van de Wet bestuur en toezicht ${ }^{36}$ per 1 januari 2013 is artikel 2:9 van het Burgerlijk Wetboek (BW) (oud) aangepast. In artikel 2:9 BW (oud) was de taak van bestuurders neergelegd. Dat is in de nieuwe redactie van het artikel - artikel 2:9 BW (nieuw) - nog steeds het geval. Het artikel is slechts nader gepreciseerd. ${ }^{37}$ Hiertoe noopte de introductie van het monistisch bestuursmodel in artikel 2:129a (239a) BW. ${ }^{38}$ Artikel 2:9 BW (nieuw) biedt, evenals zijn voorloper dat deed, ruimte voor een taakverdeling binnen het bestuur. ${ }^{39}$ Volgens de minister komt een taakverdeling de efficiëntie van het bestuur ten goede. ${ }^{40}$ Een taakverdeling brengt echter ook neveneffecten met zich. Een voorbeeld van een dergelijk neveneffect is het mogelijk hogere aansprakelijkheidsrisico dat bestuurders lopen als gevolg van een (te) ver-

31. Zie voorgestelde best practice bepaling 1.3.5.

32. Zie art. 1 lid 32 van de Wijziging Audit Richtlijn.

33. Daarover: Kersten 2016, p. 60 e.v.

34. Vgl. art. 2:78a (189a) BW.

35. Daarover reeds: Langman 2005, p. 262. Daarover tevens de consultatiereactie van de Gecombineerde Commissie Vennootschapsrecht op de voorstellen van de commissie-Van Manen (p. 3): 'De verhouding tussen de auditcommissie en de $\mathrm{RvC}$ is in het Voorstel niet steeds duidelijk.' Daarover voorts: par. 5.

36. Stb. $2011,275$.

37. Kamerstukken II 2008/09, 31763, 3, p. 7.

38. Vgl. J.B. Wezeman, Persoonlijke aansprakelijkheid van uitvoerende en niet-uitvoerende bestuurders, in: M.J. Kroeze e.a., Bestuur en toezicht (Uitgave vanwege het Instituut voor Ondernemingsrecht, deel 67), Deventer: Kluwer 2009, p. 95.

39. Art. 2:9 BW (oud) hanteerde de term 'werkkring'. Die formulering riep vragen op. Daarover: Kamerstukken II 2008/09, 31763, 3, p. 7.

40. Kamerstukken II 2010/11, 31763, C, p. 15. gaande taakverdeling binnen het vennootschapsorgaan. De overige bestuurders zouden zich in een aansprakelijkheidsprocedure immers achter een taakverdeling kunnen verschuilen. ${ }^{41}$ Met artikel 2:9 BW (nieuw) is beoogd te verduidelijken wat de gevolgen van een dergelijke takkverdeling zijn voor de aansprakelijkheidsposities van individuele bestuurders. Ik betwijfel of de wetgever daarin is geslaagd. ${ }^{42}$ Daarop kom ik later terug.

Uit het eerste lid van artikel 2:9 BW volgt dat iedere bestuurder tegenover de rechtspersoon is gehouden tot een behoorlijke vervulling van zijn taak. Tot die taak behoren alle taken die niet bij of krachtens de wet of de statuten aan één of meer andere bestuurders zijn toebedeeld. Het in dat artikel bepaalde vindt overeenkomstige toepassing ten aanzien van de taakvervulling door de raad. Dat volgt uit artikel 2:149 (259) BW.43 Volgens de memorie van toelichting bij het voorgestelde artikel 2:9 BW is bewust gekozen voor een negatieve formulering van de reikwijdte van de taak van de individuele bestuurder en commissaris. ${ }^{44}$ Daarmee is beoogd te voorkomen dat taken bij een taakverdeling tussen wal en schip belanden indien bepaalde taken niet uitdrukkelijk aan een individuele bestuurder of commissaris zijn toegedeeld. De niet aan een specifieke bestuurder of commissaris toebedeelde taken rusten namelijk op alle leden van het vennootschapsorgaan. Daaruit volgt dat de omvang van de taak van de bestuurder of commissaris een functie is van, en (mede) bepaald wordt door, een eventuele toedeling van taken aan zijn medebestuurders of -commissarissen. Daarmee bestaat een 'inverse relatie' tussen de omvang van de taak van bestuurders en commissarissen onderling: indien toedeling van een specifieke taak aan een bestuurder of commissaris plaatsvindt, dan krijgt hij niet zozeer een nieuwe taak in zijn takenpakket erbij, maar valt deze taak door de taaktoedeling in beginsel buiten het takenpakket van de overige bestuurders of commissarissen. ${ }^{45}$ Dat geldt evenzo voor een takkverdeling tussen de leden van de raad die lid zijn van een auditcommissie en zij die dat niet zijn. Met het toedelen van (aanvullende) taken aan leden van de auditcommissie neemt de omvang van het takenpakket van de leden dus niet zozeer toe, maar neemt het takenpakket van de overige commissarissen af.

Een toedeling van specifieke taken aan individuele bestuurders of commissarissen doet niet af aan het beginsel van collectieve verantwoordelijkheid binnen het vennootschapsorgaan. ${ }^{46}$ Dat beginsel houdt in dat iedere bestuurder en iedere commissaris

41. Zie Schild \& Timmerman 2014.

42. Daarin sta ik overigens niet alleen. Zie o.a. Wezeman 2009, p. 98.

43. De formulering van de schakelbepaling van art. 2:149 (259) BW is wat ongelukkig. Daarover: W.J. Slagter/B.F. Assink, Compendium ondernemingsrecht (deel 1), Deventer: Kluwer 2013, par. 13.4; C. de Groot, Drie opmerkingen bij de 'Wet bestuur en toezicht', O\&F 2013, afl. 1, p. 7.

44. Kamerstukken II 2008/09, 31763, 3, p. 7

45. Kamerstukken II 2008/09, 31763, 3, p. 7 en 26.

46. Kamerstukken II 2008/09, 31763, 3, p. 8. Bevestigd in o.a. Hof Amsterdam 21 september 2010, JOR 2011/40. Daarover: Asser/Maeijer \& Kroeze 2-I*2015/198; Slagter/Assink 2013, par. 13.2 . 


\section{Maandblad \\ Ondernemingsrecht}

verantwoordelijk is voor de algemene gang van zaken. Dat volgt uit het tweede lid van artikel 2:9 BW. Een takkerdeling kan er niet toe leiden dat het algemeen beleid aan de taak van een individuele bestuurder of commissaris wordt onttrokken. Tot dat algemeen beleid wordt onder meer het financiële beleid van de vennootschap gerekend. ${ }^{47}$ Uit datzelfde artikellid volgt dat iedere bestuurder of commissaris voor het geheel (hoofdelijk) aansprakelijk is indien sprake is van onbehoorlijk bestuur. Daarvan is in beginsel zelfs sprake als het onbehoorlijk bestuur plaatsvindt binnen de (bestuurs- of toezichts)taak van een andere bestuurder of commissaris.

Het uitgangspunt van collegialiteit binnen het vennootschapsorgaan geldt dus onverkort indien sprake is van een taakverdeling binnen het bestuur of de raad. Toch staat dit uitgangspunt binnen het vennootschapsorgaan niet in de weg aan de mogelijkheid van individuele disculpatie. De mogelijkheid tot disculpatie werkt als een correctiemiddel voor onbillijke uitkomsten. ${ }^{48}$ Dat correctiemiddel is niet bedoeld voor de situatie dat onbehoorlijk bestuur plaatsvindt op een (bestuurs- of toezichts)gebied dat wordt gerekend tot het algemeen beleid. De bestuurder of commissaris kan zich niet onttrekken aan zijn verantwoordelijkheid op dat terrein. Uit het tweede lid van artikel 2:9 BW volgt dat iedere bestuurder of commissaris voor het geheel aansprakelijk is ter zake van onbehoorlijk bestuur, tenzij hem (1), mede gelet op de aan anderen toebedeelde taken, geen ernstig verwijt kan worden gemakt en hij (2) niet nalatig is geweest in het treffen van maatregelen om de gevolgen van onbehoorlijk bestuur af te wenden. Volgens de memorie van toelichting bij dit artikel dient voor een (geslaagd) beroep op de disculpatiemogelijkheid te zijn voldaan aan beide voorwaarden: zowel de eventuele aanwezigheid van een taakverdeling als de eventuele nalatigheid van de bestuurder of de commissaris dient te worden getoetst. ${ }^{49} \mathrm{De}$ wetgever heeft met deze formulering willen aansluiten bij de rechtspraak. ${ }^{50}$ De minister lijkt daarmee echter uit te gaan van een te enge opvatting. De Hoge Raad heeft reeds in 1997 overwogen dat voor (individuele) aansprakelijkheid op de voet van artikel 2:9 BW is vereist dat de bestuurder een ernstig verwijt kan worden gemaakt. ${ }^{51}$ Daaruit volgt dat een bestuurder of commissaris niet jegens de vennootschap aansprakelijk is indien hem geen ernstig verwijt kan worden gemaakt. Of een bestuurder of commissaris in een specifiek geval een ernstig

47. Daarover o.a., met verwijzing naar jurisprudentie, Slagter/Assink 2013, par. 13.1 .

48. Zie Slagter/Assink 2013, par. 13.2.

49. Kamerstukken II $2008 / 09,31763$, 3, p. 8, alwaar wordt opgemerkt dat " $\mathrm{i}] \mathrm{n}$ de nieuwe tekst het woord "en" in het tweede lid [verzekert] dat de takkverdeling én de eventuele nalatigheid van de bestuurder om maatregelen te treffen, beide worden getoetst'. Zie voorts Kamerstukken II 2008/09, 31763, 3, p. 9: 'De bestuurder die wordt aangesproken, zal moeten aantonen dat een aangelegenheid niet tot zijn taak als bedoeld in artikel 2:9 lid 2 BW behoorde. Ook moet hij aantonen dat hij niet nalatig is geweest in het treffen van maatregelen om de gevolgen van het handelen of nalaten door de andere bestuurder, wiens taak het wel betrof, af te wenden.'

50. Kamerstukken II $2008 / 09,31763,3$, p. 8.

51. HR 10 januari 1997, NJ 1997/360 m.nt. Ma. (Staleman/Van der Ven), r.o. 3.3.1. verwijt kan worden gemaakt, dient te worden beoordeeld aan de hand van alle omstandigheden van het geval. Tot deze relevante omstandigheden behoren onder meer de taakverdeling binnen het bestuur of de raad. ${ }^{52}$ Zelfs is niet ondenkbaar dat een taakverdeling binnen het vennootschapsorgaan als een zwaarwegende omstandigheid zou kunnen worden aangemerkt. ${ }^{53}$ Ook de eventuele nalatigheid van een bestuurder of commissaris om de gevolgen van onbehoorlijk bestuur af te wenden, zou een omstandigheid kunnen zijn die wordt meegenomen bij de beantwoording van de vraag of de bestuurder of commissaris heeft geacteerd in strijd met de rechterlijke toetsingsnorm. De wetgever zou er mijns inziens goed aan doen om het tweede lid van artikel 2:9 BW zodanig te wijzigen dat iedere bestuurder of commissaris voor het geheel aansprakelijk is ter zake van onbehoorlijk bestuur, tenzij hem, mede gelet op de aan anderen toebedeelde taken en eventuele nalatigheid in het treffen van maatregelen om de gevolgen van onbehoorlijk bestuur af te wenden, geen ernstig verwijt kan worden gemaakt. Daarmee zou de wetgever, nog meer dan thans het geval is, aansluiten bij de convergentie die binnen de rechtspraak op het gebied van (interne) bestuursaansprakelijkheid plaatsvindt. $^{54}$

\section{De taakverdeling tussen leden van de auditcommissie en de overige leden van de raad nader beschouwd}

Niet ondenkbaar is dat de wetgever primair de taakverdeling tussen uitvoerende bestuurders en niet-uitvoerende bestuurders bij de aanpassing van artikel 2:9 BW voor ogen heeft gehad. Wellicht is dat de reden dat de wetgever in het bijzonder de verschillen in de aansprakelijkheidsposities van uitvoerende bestuurders en niet-uitvoerende bestuurders heeft willen verduidelijken. Toch kan niet worden miskend dat de wetgever ook rekening heeft gehouden met andersoortige taakverdelingen binnen de vennootschapsorganen. Een voorbeeld van een dergelijke taakverdeling is die tussen de leden van de raad die lid zijn van een auditcommissie en de overige leden van de raad. Over de verhouding omtrent de aansprakelijkheidspositie van deze leden en de overige leden van de raad is in de memorie van toelichting bij het voorgestelde artikel 2:9 BW het volgende opgemerkt:

'Is sprake van een vennootschap met een al dan niet op grond van Europese regels ingestelde audit commissie, dan zal de informatiepositie van een bestuurder of commissaris die geen deel uitmaakt van zo'n commissie bijvoorbeeld verschillen van degene die daar op grond van zijn bijzondere expertise wel zitting in heeft genomen. De bestuurder of

52. HR 10 januari 1997, NJ 1997/360 m.nt. Ma. (Staleman/Van der Ven), r.o. 3.3.1.

53. Vgl. HR 29 november 2002, NJ 2003/455 (Berghuizer Papierfabriek), r.o. 3.4.5, waarin de Hoge Raad overwoog dat '[d]e omstandigheid dat gehandeld is in strijd met statutaire bepalingen die de rechtspersoon beogen te beschermen, in dit verband als een zwaarwegende omstandigheid [moet] worden aangemerkt, die in beginsel de aansprakelijkheid van de bestuurder vestigt'.

54. Daarover: Slagter/Assink 2013, par. 13.2. 
commissaris die geen deel uitmaakt van de audit commissie zal zich tot op zekere hoogte mogen laten leiden door de bevindingen van de commissie. ${ }^{55}$

De minister plaatste deze opmerking expliciet in het kader van de disculpatiemogelijkheid die het voorgestelde artikel 2:9 BW bood. Daarbij merkte de minister op dat het in artikel 2:9 lid 2 BW bepaalde doorwerkt naar de aansprakelijkheid van commissarissen. ${ }^{56}$ Het risico daarvan is dat deze kanttekening de verhouding tussen leden van de auditcommissie en de overige leden van de raad niet heeft verduidelijkt, maar juist verder lijkt te vertroebelen. Zo is niet nader geillustreerd tot op welke hoogte de commissaris die geen lid is van de auditcommissie zich mag laten leiden door de bevindingen van de leden die daar wel zitting in hebben genomen. ${ }^{57}$ Daarnaast is niet duidelijk of de commissaris die op grond van zijn bijzondere expertise zitting heeft genomen in de auditcommissie (vergelijk de financieel expert), op basis van de voordelige(r) informatiepositie die hij inneemt, zich minder snel kan disculperen c.q. sneller een ernstig verwijt kan worden gemaakt indien sprake is van onbehoorlijk bestuur. ${ }^{58}$ En tot slot bestaat in dit verband onduidelijkheid over de verschillen in aansprakelijkheidsrisico tussen de leden van de auditcommissie onderling, waarbij met name het onderscheid tussen de voorzitter, de financieel expert en de overige leden van de auditcommissie relevant zal zijn.

Het scheppen van duidelijkheid omtrent de verhouding tussen leden van de auditcommissie en de overige leden van de raad is met name relevant wanneer we de recente ontwikkelingen in geagendeerde wet- en regelgeving, zoals beschreven in paragraaf 2 , bezien vanuit het perspectief van de inverse relatie' die bestaat tussen leden van de raad onderling. Indien toedeling van aanvullende toezichtstaken aan de leden van de auditcommissie zal plaatsvinden, zal in beginsel de omvang van de taak van de overige leden van de raad (verder) afnemen. ${ }^{59}$ In dat kader is het de vraag of een ver(der)gaande taakverdeling tussen leden van de auditcommissie en de overige leden van de raad nog wenselijk is, en indien dit wenselijk wordt geacht, op welke specifieke toezichtsgebieden de nadere taakverdeling wenselijk is. Zo stelde Kersten onlangs dat het intern toezicht op andere gebieden dan de beheersing van de risico's op het gebied van financiële verslaggeving meer bij een risicocommissie dan bij een auditcommissie past. ${ }^{60}$ Vergelijkbare vragen zijn gesteld in de reacties op de voorstellen die de commissie-Van Manen begin dit jaar ter consultatie heeft

55. Kamerstukken II 2008/09, 31763, 3, p. 9.

56. Kamerstukken II 2008/09, 31763, 3, p. 9.

57. Daarover: Kersten 2016, p. 57.

58. Zie Slagter/Assink 2013, par.13.2, waarin Assink opmerkt dat bijzondere, van de objectieve ondergrens van de (objectieve maatman-)bestuurder te onderscheiden, subjectieve kennis en/of kunde ertoe kunnen leiden dat een bepaalde suboptimale handelwijze eerder tot een toerekenbare normschending zal leiden. Daarover tevens: L. Timmerman, Beginselen van bestuurdersaansprakelijkheid, WPNR 2016/7105, randnr. 13

59. Zie daarover par. 3 .

60. Kersten 2016, p. 62. voorgelegd. ${ }^{61}$ Gegeven het bestaan van deze vragen kan worden geconcludeerd dat de tendens om (aanvullende) toezichtstaken van de raad aan de auditcommissie te doen uitbesteden, gepaard lijkt te gaan met een (nadere) vertroebeling van de verhouding tussen de leden van de raad die lid zijn van een auditcommissie en de leden van de raad die dat niet zijn.

\section{Slot}

Met de inwerkingtreding van de Wet op de jaarrekening van ondernemingen is afscheid genomen van het onderscheid tussen de balanscommissaris en de overige leden van de raad. Het toezicht op, en de verantwoordelijkheid voor, de jaarrekening werd als een dermate essentieel onderdeel van de taak van de raad beschouwd dat geen van zijn leden hiervan zou mogen worden ontheven. Daaruit volgt dat het toezicht op de financiële verslaggeving werd beschouwd als een kerntaak van de raad. Een vergelijkbaar onderscheid kan worden gemaakt tussen de leden van de raad die lid zijn van een auditcommissie en zij die dat niet zijn. De introductie van de auditcommissie in het Nederlandse vennootschapsrecht, en de mogelijke gevolgen van een dergelijke taakverdeling tussen leden van de auditcommissie en de overige leden van de raad, heeft in de literatuur betrekkelijk veel stof doen opwaaien.

Recente ontwikkelingen accentueren de onduidelijkheid die er bestaat over de verhouding tussen de verantwoordelijkheid van de leden van de auditcommissie en de overige commissarissen. De te implementeren Audit Richtlijn en de Audit Verordening stellen aanvullende eisen aan het toezicht zoals dat door de leden van de auditcommissie dient te worden uitgeoefend. De voorstellen van de commissie-Van Manen doen daar nog een schepje bovenop. Deze ver(der)gaande taakverdeling accentueert het onderscheid tussen leden van de auditcommissie en de overige leden van de raad, als gevolg waarvan de onduidelijkheid omtrent de verschillen in aansprakelijkheidsrisico tussen leden van de auditcommissie en de overige leden van de raad naar verwachting - nog verder - zal toenemen.

De gedachte is dat een taakverdeling binnen de raad leidt tot efficiënter toezicht. Het voorkomt dat meerdere leden zich met dezelfde toezichtstaken bezighouden. De gedachte achter het opheffen van het onderscheid tussen de balanscommissaris en de overige leden van de raad is dat het toezicht op de financiële verslaggeving als een van de kerntaken van de raad wordt beschouwd. De vraag is of die gedachte nog houdbaar is. Datzelfde geldt - meer in het algemeen - voor het beginsel van collectieve verantwoordelijkheid binnen de raad, dat nog steeds onverkort van toepassing is en ook geldt ten aanzien van de gebieden waarop de auditcommissie behoort toe te zien. De (Europese) wetgever moet balanceren tussen een

61. Zie de consultatiereactie van de Gecombineerde Commissie Vennootschapsrecht, p. 3: 'De verhouding tussen de auditcommissie en de $\mathrm{RvC}$ is in het Voorstel niet steeds duidelijk.' Zie voorts o.a. de consultatiereacties van de Nederlandse Vereniging van Banken, p. 4, Stibbe, p. 6 en Houthoff Buruma, p. 3. 


\section{Maandblad}

Ondernemingsrecht

ver(der)gaande functionele taakverdeling en het uitgangspunt van collegialiteit binnen de raad. Van belang is dat hij het evenwicht niet verliest. 